\title{
ANALISIS PENERAPAN STANDAR NASIONAL PELAYANAN KESEHATAN PEDULI REMAJA (PKPR) PADA PUSKESMAS PKPR DI KABUPATEN LEBAK TAHUN 2016
}

\author{
*Een Sukaedah,* Suhartini
}

\begin{abstract}
Abstrak
Kelompok remaja adalah penduduk dalam rentang usia 10-19 tahun. Kelompok ini di Indonesia memiliki proporsi kurang lebih 1/5 dari jumlah seluruh penduduk. Jumlah ini sesuai dengan proporsi remaja di dunia dimana jumlah remaja diperkirakan 1,2 miliar atau sekitar 1/5 dari jumlah penduduk dunia (WHO,2003). Melihat jumlahnya yang sangat besar, maka remaja sebagai generasi penerus bangsa perlu dipersiapkan menjadi manusia yang sehat secara jasmani, rohani, mental dan spiritual. Puskesmas sebagai pusat layanan kesehatan terbawah dan terdekat dengan masyarakat memiliki andil yang cukup penting dalam optimalisasi Pelayanan Kesehatan Peduli Remaja (PKPR) di puskesmas. Pelayanan Kesehatan Peduli remaja di kabupaten Lebak telah dilaksanakan di 5 (lima) Puskesmas,yang aktif melaksanakan program PKPR ada tiga puskesmas, namun sejauhmana penerapan standar nasional layanan PKPR di 3 (tiga) puskesmas ini belum diketahui. Tujuan penelitian ini untuk menganalisis sejauhmana penerapan Standar Nasional PKPR pada puskesmas PKPR di kabupaten Lebak tahun 2016

Metodelogi penelitian ini dengan menggunakan desain "Cross sectional". Populasi penelitian adalah seluruh pimpinan puskesmas, pengelola program PKPR di puskesmas, petugas pendukung dan remaja yang memanfaatkan layanan PKPR di masing-masing puskesmas. Sampel penelitian ini sama dengan populasi. Lokasi penelitian dilakukan di 3 (tiga) Puskesmas yang melaksanakan kegiatan PKPR yaitu; puskesmas Rangkasbitung, Cibadak, dan Cipanas. Kegiatan Penelitian dilaksanakan sejak bulan Agustus sampai dengan Desember tahun 2016

Hasil penelitian menunjukkan bahwa pencapaian standar SN-PKPR di tiga puskesmas yaitu; puskesmas Cibadak 53\%, Rangkasbitung 50\%, dan Cipanas 37\%). Ketiga puskesmas tingkat pemenuhan Standar SN-PKPR masih minimal $(<60 \%)$ atau garis merah. angka pencapaian standar SDM tertinggi $72 \%$ terendah $43 \%$. angka capaian fasilitas tertinggi $76 \%$ dan terndah $62 \%$. angka capaian remaja tertinggi $50 \%$, terendah $10 \%$, angka capaian jejaring tertinggi $33 \%$ terendah $11 \%$, angka capaian manajemen kesehatan tertinggi $33 \%$ terendah $7 \%$.

Mengingat secara keseluruhan pencapaian SN-PKPR di tiga puskesmas masih rendah, untuk itu disarankan perlu disusun rencana aksi (workplan), agar pelaksanaan kegitan PKPR di puskesmas dapat berjalan sebagaimana mestinya. Dukungan dari Kepala Dinas Kesehatan, Kepala Puskesmas dan institusi terkait lainnya sangat diperlukan dalam mendukung kegiatan Pelayanan Kesehatan Peduli Remaja (PKPR) di puskesmas Rangkasbitung, Cibadak, Cipanas kabubaten Lebak.
\end{abstract}

Daftar Pustaka; 11 ( $2003-2014$ )

Kata Kunci; Remaja, Puskesmas,PKPR

*) Poltekkes Kemenkes Banten 


\section{Pendahuluan}

Kelompok remaja adalah penduduk dalam rentang usia 10-19 tahun. Kelompok ini di Indonesia memiliki proporsi kurang lebih 1/5 dari jumlah seluruh penduduk. Jumlah Ini sesuai dengan proporsi remaja di dunia dimana jumlah remaja diperkirakan 1,2 miliar atau sekitar 1/5 dari jumlah penduduk dunia (WHO, 2003). Berdasarkan data proyeksi penduduk Indonesia 2000-2005, proporsi remaja berusia 10-19 tahun pada tahun 2010 adalah sekitar $18,3 \%$ dari total penduduk atau sekitar 43 juta jiwa. Pada tahun 2010 jumlah remaja umur 10-24 tahun sangat besar yaitu sekitar 64 juta atau $27,6 \%$ dari jumlah Penduduk Indonesia sebanyak 237,6 juta jiwa (Sensus Penduduk, 2010).

Masa remaja merupakan masa peralihan dari anak-anak kemasa dewasa. Kehidupan remaja merupakan kehidupan yang sangat menentukan bagi kehidupan masa depan mereka selanjutnya. Melihat jumlahnya yang sangat besar, maka remaja sebagai generasi penerus bangsa perlu dipersiapkan menjadi manusia yang sehat secara jasmani, rohani, mental dan spiritual. Pentingnya remaja sebagai aset masa depan peradaban manusia ditunjukkan dengan adanya beberapa indikator yang ditetapkan Persatuan Bangsa-Bangsa sebagai Millenium
Development Goals meliputi; tingkat melek huruf penduduk usia 15-24 tahun, Proporsi penduduk usia 15-24 tahun yang memiliki pengetahuan komprehensif terhadap HIV-AIDS, ratio partisipasi sekolah anak usia 10-14 yang tidak yatim dan yang yatim piatu.

Faktanya, berbagai penelitian menunjukkan bahwa remaja mempunyai permasalahan yang sangat kompleks seiring dengan masa transisi yang dialami remaja. Masalah yang menonjol dikalangan remaja yaitu permasalahan seputar Triad KRR (Seksualitas, HIV dan AIDS serta Napza), rendahnya pengetahuan remaja tentang Kesehatan Reproduksi Remaja dan median usia kawin pertama perempuan relatif masih rendah yaitu 19,8 tahun (SDKI 2007). Hasil SDKI tahun 2012 menunjukan bahwa pengetahuan remaja tentang kesehatan reproduksi belum memadai. Hanya 35,3\% remaja perempuan dan 31,2\% remaja laki-laki umur 15-19 tahun mengetahui bahwa perempuan dapat hamil dengan satu kali berhubungan seksual. Sebanyak $41,2 \%$ perempuan dan $55,3 \%$ laki-laki umur 15-19 tahun mengetahui bahwa cara penularan HIV-AIDS dapat dikurangi jika berhubungan seks hanya dengan seseorang yang tidak memiliki pasangan lain. $46 \%$ perempuan dan 60,8 \% laki-laki umur 15-19 tahun mengetahui bahwa penularan HIV-AIDS dapat 
dikurangi dengan menggunakan kondom. Hanya $9,9 \%$ perempuan dan $10,6 \%$ lakilaki umur 15-19 tahun memiliki pengetahuan komprehensif mengenai HIV-AIDS.

Masa remaja merupakan periode terjadinya pertumbuhan dan perkembangan pesat baik fisik, psikologis maupun intelektual. Pola karakteristik pesatnya tumbuh kembang ini menyebabkan remaja dimanapun ia menetap, mempunyai sifat khas yang sama yaitu mempunyai rasa keingintahuan yang besar, menyukai petualangan dan tantangan serta cenderung berani menanggung risiko atas perbuatannya tanpa didahului oleh pertimbangan yang matang. Sifat tersebut dihadapkan pada ketersediaan sarana di sekitarnya yang dapat memenuhi keingintahuan tersebut. Keadaan ini sering kali mendatangkan konflik batin dalam diriya. Apabila keputusan yang diambil dalam menghadapi konflik tidak tepat, mereka akan jatuh ke dalam perilaku berisiko dan mungkin harus menanggung akibat lanjutnya dalam bentuk berbagai masalah kesehatan fisik dan psikososial, yang bahkan mungkin harus ditanggung seumur hidupnya.

Banyaknya masalah yang dihadapi oleh remaja tersebut, dirasakan perlu penanganan yang cepat dan tepat mengingat remaja secara biologis merupakan calon ayah dan ibu namun belum dewasa, sehingga dirasakan perlu penyediaan layanan yang berkualitas bagi remaja. Program kesehatan remaja sudah mulai diperkenalkan di puskesmas sejak awal dekade yang lalu. Selama lebih sepuluh tahun, program ini lebih banyak bergerak dalam pemberian informasi, berupa ceramah, tanya jawab dengan remaja tentang masalah kesehatan. Puskesmas sebagai pusat layanan kesehatan terbawah dan terdekat dengan masyarakat memiliki andil yang cukup penting dalam optimalisasi pelayanan kesehatan peduli remaja di puskesmas. Beberapa model pelayanan kesehatan remaja yang memenuhi kebutuhan dan "selera" remaja telah diperkenalkan dengan sebutan Pelayanan Kesehatan Peduli Remaja atau disingkat PKPR. Pelayanan ini meliputi upaya promotif, preventif, kuratif dan rehabilitatif. Sesuai permasalahannya, aspek yang perlu ditangani lebih intensif adalah aspek promotif dan preventif, dengan pendekatan "peduli remaja ".

Mengingat kebutuhan remaja dan memperhitungkan tugas puskesmas sebagai barisan terdepan pemberi layanan kesehatan kepada masyarakat, seharusnya Puskesmas memberikan pelayanan yang layak kepada remaja sebagai salah satu kelompok masyarakat 
yang dilayaninya. Pelayanan kesehatan remaja di puskesmas amat strategis dan dapat dilaksanakan dengan efektif dan efisien mengingat ketersediaan tenaga kesehatan dan kesanggupan jangkauan Puskesmas ke segenap penjuru Indonesia seperti halnya keberadaan remaja sendiri, yang tersebar dari daerah perkotaan hingga terpencil perdesaan

Pelayanan Kesehatan Peduli remaja di kabupaten Lebak telah dilaksanakan di 5 (lima) Puskesmas, kelima puskesmas tersebut aktif melaksanakan program PKPR, namun sejauhmana penerapan standar nasional layanan PKPR di wilayah ini belum diketahui karena belum pernah dilakukan evaluasi oleh Dinas Kesehatan setempat, sehingga perlu diadakan penelitian terkait implementasinya di lapangan apakah sudah sesuai dengan standar nasional Pelayanan Kesehatan Peduli Remaja (SN-PKPR). Pada penelitian ini mengingat pertimbangan lokasi puskesmas, maka penelitian dilakukan di tiga Puskesmas yang melaksanakan kegiatan PKPR di kabupaten Lebak yaitu; Puskesmas, Rangkasbitung, Cibadak, dan Cipanas

\section{Metode}

Desain penelitian ini penelitian Deskriptif kuantitatif. Metode penelitian ini pada dasarnya merupakan cara ilmiah untuk mendapatkan data dengan tujuan dan kegunaan tertentu. dengan empat kunci; cara ilmiah, data, tujuan dan kegunaan. Secara umum tujuan penelitian bersifat penemuan, pembuktian dan pengembangan. Pada penelitian ini bersifat penemuan artinya data yang betul-betul baru dan sebelummnya belum pernah diketahui.

Penelitian dilaksanakan di 3 (Tiga) Puskesmas dengan PKPR yang telah terbentuk di kabupaten Lebak yaitu; Puskesmas Rangkasbitung dan Puskesmas , Cibadak, dan Cipanas, dengan pertimbangan lokasi masih berdekatan dengan Dinas Kesehatan setempat, sehingga lebih mudah untuk dilekukan pemantauan.

Sampel penelitian sama dengan populasi. Tehnik pengambilan sampelnya adalah non probability sampling yaitu tehnik pengambilan sampel yang tidak memberikan peluang /kesempatan sama bagi setiap unsur atau anggota populasi untuk dipilih sebagai sampel.. Tehnik pengambilan sampel pada penelitian ini menggunakan tehnik purposive sampling yaitu pengambilan sampel sumber data dengan pertimbangan tertentu. 


\section{Hasil}

Tabel 1

Tingkat Pemenuhan Standar Nasional

Pelayanan Kesehatan Peduli Remaja

(SN-PKPR) Puskesmas Rangkasbitung Tahun 2016

\begin{tabular}{|l|c|c|c|}
\hline STANDAR & $\begin{array}{c}\text { SKOR } \\
\text { MAKSI } \\
\text { MAL }\end{array}$ & $\begin{array}{c}\text { SKOR } \\
\text { YANG } \\
\text { DICAPAI }\end{array}$ & $\begin{array}{c}\text { TINGKAT } \\
\text { PEMENU } \\
\text { HAN (\%) }\end{array}$ \\
\hline $\begin{array}{l}\text { Standar 1 } \\
\text { SDM } \\
\text { Kesehatan }\end{array}$ & 60 & 41 & 68 \\
\hline $\begin{array}{l}\text { Standar 2 } \\
\text { Fasilitas }\end{array}$ & 124 & 94 & 76 \\
\hline $\begin{array}{l}\text { Standar 3 } \\
\text { Remaja }\end{array}$ & 70 & 23 & 22 \\
\hline $\begin{array}{l}\text { Standar 4 } \\
\text { Jejaring }\end{array}$ & 18 & 6 & 33 \\
\hline $\begin{array}{l}\text { Standar 5 } \\
\text { Manajemen } \\
\text { Kesehatan }\end{array}$ & 70 & 7 & 10 \\
\hline $\begin{array}{l}\text { Standar } \\
\text { Nasional } \\
\text { PKPR }\end{array}$ & 342 & 171 & 50 \\
\hline \multicolumn{2}{|l|}{ INTERPRETASI STANDAR } & Minimal \\
\hline
\end{tabular}

Pada tabel 1.1 terlihat bahwa pemenuhan standar SDM Kesehatan tingkat pemenuhan cukup baik yaitu dengan tingkat pemenuhan mencapai $68 \%$. Demikian pula dengan standar fasilitas tingkat pemenuhannya mencapai $76 \%$, namun untuk pemenuhan standar remaja baru mencapai $(22 \%)$ ,jejaring (33\%) dan standar manajemen masih belum memenuhi tingkat pemenuhan yang diharapkan (10\%). Secara umum tingkat penuhan standar mencapai $50 \%$ dan dikatagorikan mencapai standar minimal.
Tabel 2

Tingkat Pemenuhan Standar Nasional Pelayanan Kesehatan Peduli Remaja (SN-PKPR)Puskesmas Cibadak Tahun 2016

\begin{tabular}{|l|c|c|c|}
\hline STANDAR & $\begin{array}{c}\text { SKOR } \\
\text { MAKSIM } \\
\text { AL }\end{array}$ & $\begin{array}{c}\text { SKOR } \\
\text { YANG } \\
\text { DICAPA } \\
\text { I }\end{array}$ & $\begin{array}{c}\text { TINGKAT } \\
\text { PEMENUHA } \\
\text { N (\%) }\end{array}$ \\
\hline $\begin{array}{l}\text { Standar 1 } \\
\text { SDM } \\
\text { Kesehatan }\end{array}$ & 60 & 43 & 72 \\
\hline $\begin{array}{l}\text { Standar } 2 \\
\text { Fasilitas }\end{array}$ & 124 & 77 & 62 \\
\hline $\begin{array}{l}\text { Standar 3 } \\
\text { Remaja }\end{array}$ & 70 & 35 & 50 \\
\hline $\begin{array}{l}\text { Standar 4 } \\
\text { Jejaring }\end{array}$ & 18 & 2 & 11 \\
\hline $\begin{array}{l}\text { Standar 5 } \\
\text { Manajemen } \\
\text { Kesehatan }\end{array}$ & 70 & 23 & 33 \\
\hline $\begin{array}{l}\text { Standar } \\
\text { Nasional } \\
\text { PKPR }\end{array}$ & 342 & 180 & 53 \\
\hline \multicolumn{2}{|c|}{ INTERPRETASI STANDAR } & Minimal \\
\hline
\end{tabular}

Pada table 1.2 terlihat bahwa pemenuhan standar SDM Kesehatan tingkat pemenuhan cukup baik yaitu dengan tingkat pemenuhan mencapai $72 \%$. Demikian pula dengan standar fasilitas tingkat pemenuhannya mencapai $62 \%$, namun untuk pemenuhan standar remaja baru mencapai $(50 \%)$,jejaring (11\%) dan standar manajemen masih belum memenuhi tingkat pemenuhan yang diharapkan (33\%). Secara umum tingkat penuhan standar mencapai $53 \%$ dan dikatagorikan mencapai standar minimal. 
Tabel 3

Tingkat Pemenuhan Standar Nasional Pelayanan Kesehatan Peduli Remaja

(SN-PKPR) Puskesmas Cipanas Tahun 2016

\begin{tabular}{|l|c|c|c|}
\hline \multicolumn{1}{|c|}{ STANDAR } & $\begin{array}{c}\text { SKOR } \\
\text { MAKS } \\
\text { IMAL }\end{array}$ & $\begin{array}{c}\text { SKOR } \\
\text { YANG } \\
\text { DICAPA } \\
\text { I }\end{array}$ & $\begin{array}{c}\text { TINGKAT } \\
\text { PEMENUHA } \\
\text { N }(\%)\end{array}$ \\
\hline $\begin{array}{l}\text { Standar 1 SDM } \\
\text { Kesehatan }\end{array}$ & 60 & 26 & 43 \\
\hline $\begin{array}{l}\text { Standar 2 } \\
\text { Fasilitas }\end{array}$ & 124 & 88 & 71 \\
\hline $\begin{array}{l}\text { Standar 3 } \\
\text { Remaja }\end{array}$ & 70 & 7 & 10 \\
\hline $\begin{array}{l}\text { Standar 4 } \\
\text { Jejaring }\end{array}$ & 18 & 2 & 11 \\
\hline $\begin{array}{l}\text { Standar 5 } \\
\text { Manajemen } \\
\text { Kesehatan }\end{array}$ & 70 & 5 & 7 \\
\hline $\begin{array}{l}\text { Standar } \\
\text { Nasional PKPR }\end{array}$ & 342 & 128 & 37 \\
\hline \multicolumn{2}{|c|}{ INTERPRETASI STANDAR } & Minimal \\
\hline
\end{tabular}

Pada table 1.3 terlihat bahwa pemenuhan standar SDM Kesehatan tingkat pemenuhan masih belum baik yaitu dengan tingkat pemenuhan $43 \%$. Standar fasilitas cukup baik tingkat pemenuhannya mencapai $71 \%$, namun untuk pemenuhan standar remaja baru mencapai $(10 \%)$,jejaring (11\%) dan standar manajemen masih belum memenuhi tingkat pemenuhan yang diharapkan $(7 \%)$. Secara umum tingkat penuhan standar mencapai $37 \%$ dan dikatagorikan mencapai standar minimal.
Tabel 4

Rekapitulasi Tingkat Pemenuhan Masing-Masing Standar Pelayanan Kesehatan Peduli Remaja Di Puskesmas PKPR Kabupaten Lebak 2016

\begin{tabular}{|c|c|c|c|}
\hline STANDAR & PUSKESMAS & SKOR & $\begin{array}{l}\text { TINGKAT } \\
\text { PEMENUH } \\
\text { AN }(\%)\end{array}$ \\
\hline \multirow[t]{3}{*}{$\begin{array}{l}\text { 1.SDM } \\
\text { KESEHATAN }\end{array}$} & $\begin{array}{l}\text { RANGKASBI } \\
\text { TUNG }\end{array}$ & 41 & 68 \\
\hline & CIBADAK & 43 & 72 \\
\hline & CIPANAS & 26 & 43 \\
\hline \multirow[t]{3}{*}{ 2.FASILITAS } & $\begin{array}{l}\text { RANGKASBI } \\
\text { TUNG }\end{array}$ & 94 & 76 \\
\hline & CIBADAK & 77 & 62 \\
\hline & CIPANAS & 88 & 71 \\
\hline \multirow[t]{3}{*}{ 3.REMAJA } & $\begin{array}{l}\text { RANGKASBI } \\
\text { TUNG }\end{array}$ & 23 & 22 \\
\hline & CIBADAK & 35 & 50 \\
\hline & CIPANAS & 7 & 10 \\
\hline \multirow[t]{3}{*}{ 4.JEJARING } & $\begin{array}{l}\text { RANGKASBI } \\
\text { TUNG }\end{array}$ & 6 & 33 \\
\hline & CIBADAK & 2 & 11 \\
\hline & CIPANAS & 2 & 11 \\
\hline \multirow{3}{*}{$\begin{array}{l}\text { 5.MANAJEME } \\
\mathrm{N} \\
\text { KESEHATAN }\end{array}$} & $\begin{array}{l}\text { RANGKASBI } \\
\text { TUNG }\end{array}$ & 7 & 10 \\
\hline & CIBADAK & 23 & 33 \\
\hline & CIPANAS & 5 & 7 \\
\hline
\end{tabular}

Pada tabel 1.4 terlihat bahwa, Tingkat pemenuhan kebutuhan SDM tertinggi puskesmas Cibadak (72\%) sedangkan untuk fasilitas tertinggi puskesmas Rangkasbitung (76\%). Untuk konselor remaja tertinggi puskesmas Cibadak (50\%), sedangkan untuk jejaring SKOR tertinggi puskesmas Rangkasbitung dan cibadak baru mencapai (33\%) 


\section{Pembahasan}

Dari hasil penelitian diketahui bahwa secara umum petugas PKPR yang memegang program PKPR sudah terlatih PKPR, namun bukti pelatihan berupa sertifikat belum diperoleh oleh petugas PKPR, bukti pelatihan berupa foto maupun catatan hasil kegiatan pelatihan. Sebaiknya bukti tertulis berupa sertifikat perlu diberikan kepada petugas, sehingga dalam membuat kriteria pengelola program dapat ditunjukkan dengan adanya bukti sertifikat sehingga petugas yang bersangkutan dinyatakan layak memegang program Pelayanan Kesehatan Peduli Remaja di Puskesmas.

Untuk pemegang program sebaiknya di SK kan sehinngga legalitas petugas PKPR terjamin, Bagi Puskesmas yang telah menyusun SK Tim sebaiknya melampirkan uraian tugad pokok dan fungsi petugas PKPR, sehingga petugas dapat menjalankan kegiatan sesuai dengan tugas pokok dan fungsi yang di berikan kepadanya.

\section{Fasilitas Kesehatan}

Paket pelayan kesehatan peduli remaja

Dari hasil penelitian secara umum diketahui bahwa sudah tersedia pedoman pelayanan PKPR di dalam maupun diluar gedung. Pedoman ini sangat penting, dan dapat dijadikan acuan bagi petugas PKPR di Puskesmas dalam menjalankan kegiatan yang ada.serti; pencegahan penaggulangan anemia dan masalah gizi, tumbuh kembang remaja, kesehatan reproduksi remaja, pencegahan dan penanggulangan masalah kesehatan jiwa, pencegahan dan penaggulangan NAFZA, pencegahan dan penanggulangan kekerasan, pencegahan, deteksi dan penanggulangan; ISR,IMS, HIV-AIDS, Tuberculosis, Penaggulangan kecacingan, TT Remaj, dan kehamilan pada remaja (Kurikulum Pelatihan Training of Trainer (TOT) Pelayanan Kesehatan Usia Sekolah dan Remaja tahun 2016 Materi inti (1-5) dan Materi penunjang (1-4)

\section{Remaja}

1. Kegiatan KIE

Hasil penelitian dari tiga puskesmas belum ditemukan catatan tentang berbagai sektor terkait yang dapat menyelenggarakan pemberian informasi melalui KIE , termasuk pembagian peran dan fungsinya, serta kualifikasi ketenagaan serta catatan tentang dana serta alokasi dana misalnnya melalui BOK, APBD dll, termasuk dana dari sector terkait yang dapat digunakan untuk menyelenggarakan kegiatan pemberian 
informasi (KIE bagi remaja). Materi dan bahan-bahan serta alat bantu audiovisual tersedia walaupun dengan keterbatasan yang ada terdiri dari bukubuku pedoman atau petunjuk kegiatan PKPR. Di tiga Puskesmas juga belum ditemukan catatan/laporan tentang pelaksanaan kegiatan pemberian informasi (pelayanan KIE) bagi remaja mengenai Pertumbuhan, perkembangan, Perilaku seksual berisiko dan bahaya penggunaan NAPZA, IMS,PMS, HIVAIDS serta bahaya pernikahan dini dan kehamilan yang tidak dikehendaki.

\section{Konselor Sebaya}

Dari hasil penelitian di tiga puskesmas belum ditemukan laporan/catatan pemberian materi/pelatihan atau orientasi konselor sebaya (sebagai fasilitator). Di bebarapa puskesmas sudah ada kegiatan pembinaan konselor sebaya, namun hanya lisan dan tidak ditemukan catatan tertulis. Bukti tertulis ini penting untuk lebih meyakinkan bahwa kegiatan memang sudah terlaksana dengan baik. Pedoman konselor sebaya, sudah ada buku pedoman tentang tehnik konseling kesehatan remaja bagi konselor sebaya (Direktorat Bina Kesehatan Anak, Dirjend Bina Gizi Kemenkes RI 2010). Hendaknya pedoman ini dimanfaatkan dengan baik oleh petugas PKPR Puskesmas.

\section{Jejaring}

1. Pemetaan Pemangku kepentingan

Hasil penelitian di tiga puskesmas belum ditemukan Laporan/catatan pelaksanaan pemangku kepentingan dalam bidang kesehatan remaja dalam hal perencanaan, pelaksanaan dan tindaklanjut. Untuk itu perlu dibentuk jejaring.

Penggalangan kemitraan, dengan membangun kerjasama atau jejaring kerja. Meskipun keempat aspek upaya kesehatan (promotif, preventif, kuratif dan rehabilitatif) menjadi tugas keseharian Puskesmas, namun melihat kompleks dan luasnya masalah kesehatan remaja, kemitraan merupakan suatu hal yang esensial khususnya untuk upaya promotif dan preventif. Penggalangan kemitraan didahului dengan advokasi kebijakan publik, sehingga adanya PKPR di puskesmas dapat pula dipromosikan oleh pihak lain, dan selanjutnya dikenal dan didukung oleh masyarakat. Selain itu, kegiatan di luar gedung, yang menjadi bagian dari kegiatan PKPR, amat memerlukan kemitraan dengan pihak di luar kesehatan. Kegiatan berupa KIE, serta Pendidikan Keterampilan Hidup Sehat/PKHS (life Skills Education/LSE) seperti ceramah, diskusi, role play, 
seperti halnya konseling, dapat dilakukan oleh petugas terlatih di luar sektor kesehatan dan LSM.

\section{Partisipasi Remaja}

Hasil penelitian di tiga puskesmas belum ditemukan catatan/bukti keikutsertaan remaja dalam perencanaan, pelaksanaan dan pemantauan PKPR

Penyertaan remaja secara aktif diprrlukan dalam semua aspek pelayanan mulai perencanaan, pelaksanaan pelayanan dan evaluasi, remaja secara aktif diikut-sertakan. Dalam menyertakan remaja dianjurkan dipilih kelompok remaja laki-laki dan perempuan yang dapat "bersuara" mewakili Puskesmas untuk informasi penyediaan pelayanan kepada sebayanya dan sebaliknya

mewakili sebayanya meneruskan keinginan, kebutuhan, dan harapannya berkaitan dengan penyediaan pelayanan. Selain itu dengan keterlibatan remaja ini, informasi pelayanan dapat cepat meluas, menjangkau baik remaja lakilaki maupun perempuan,serta memperkenalkan lebih awal konsep keadilan dan kesetaraan gender.

\section{Manajemen Kesehatan}

1. Advokasi

Hasil penelitian di tiga Puskesmas belum ditemukan laporan/catatan advokasi dalam bentuk dokumen kegiatan advokasi (Foto, laporan, daftar hadir dll)

Kegiatan ini merupakan upaya untuk mempengaruhi kebijakan publik melaui berbagaibentuk komunikasi persuasif. Yang dimaksud kebijakan publik adalah pernyataan,kebijakan dari penguasa (praktek yang diberlakukan akibat dorongan/kesan yang ditimbulkan penguasa) dengan tujuan mengarahkan dan mengendalikan institusi,masyarakat, atau individu.

Dengan advokasi ini diharapkan akan menghasilkan tim atau jejaring kerjasama di wilayah kerja untuk mendapatkan dukungan semua pihak hingga dapat mempercepat keberhasilan pembentukan dan pelaksanaan PKPR.

\section{Pencatatan Pelaporan}

Dari hasil penelitian di tiga puskesmas ditemukan pedoman dan format pencatatan pelaporan, dari hasil pengamatan baru satu puskesmas yang mengirimkan pelaporan hasil kegiatan PKPR di puskesmas termasuk kunjungan kasus. Pencatatan pelaporan ini penting untuk memantau 
pelaksanaan kegiatan yang yang telah dilaksanakan.

3. Evaluasi diri, Pemantauan, Penilaian

Monitoring PKPR di puskesmas selain dilakukan oleh pihak lain di luar puskesmas perlu dilakukan oleh puskesmas sendiri. Berdasarkan hasil penelitian diketahui bahwa baru satu puskesmas yang mencoba melakukan evaluasi diri, namun sayangnya belum dinilai dengan baik sesuai matriks penilaian yang ada (Panduan SN-PKPR Kemenkes RI 2014). Melalui monitoring, petugas akan dibantu menemukan masalah secara dini hingga koreksi yang akan dilakukan tidak memerlukan biaya dan waktu yang banyak, dan mempercepat tecapainya PKPR yang berkualitas.Monitoring oleh tatanan administrasi yang lebih tinggi dilakukan melalui analisa laporan rutin yang dikirimkan oleh Puskesmas dikombinasikan dengan pengamatan langsung dilapangan.

\section{Jejaring dan Sitem Rujukan}

Dari hasil penelitian di tiga puskesmas belum ditemukan daftar instansi/ institusi untuk melakukan rujukan baik medic, hukum ataupun social, walaupun secara tidak tersirat kegiatan ini pernah dilakukan. Dan belum ditemukan daftar kasus rujukan medik, hukum maupun social serta tujuan rujukan. Sebaiknya perlu dituangkan dalam MOU dengan instansi/institusi terkait

\section{Simpulan}

1. Capaian kegiatan Pelayanan Kesehatan Peduli Remaja (PKPR) di tiga Puskesmas secara keseluruhan tingkat pemenuhan dibawah $<60 \%$ ( Rangkasbitung 50\% , Cibadak 53\% dan Cipanas 37\%) dan ketiga Puskesmas dengan tingkat pemenuhan Standar berada pada standar minimal (merah)

2. Tingkat Capaian SDM Kesehatan Skor tertinggi Puskesmas cibadak (72\%), sedangkan Puskesmas Rangkasbitung $68 \%$ dan cipanas $43 \%$

3. Tingkat capaian fasilitas kesehatan Skor tertinggi puskesmas Rangkasbitung (76\%) Cipanas 71 dan Cibadak 62\%s

4. Tingkat capaian remaja lebih dari separuh rendah. Skor tertinggi puskesmas Cibadak dengan tingkat pemenuhan (50\%), Rangkasbitung $22 \%$, Cipanas $10 \%$

5. Tingkat capaian Jejaring, masih sangat rendah, Skor tertinggi Rangkasbitung (33\%) 
6. Tingkat capaian manajemen

kesehatan masih sangat rendah Skor

tertinggi Cibadak (33\%)

\section{Daftar Pustaka}

Depkes RI, UNFA, Pedoman operasional pelayanan kesehatan reproduksi di Puskesmas, Jakarta 2003

Depkes RI, Pedoman Pelayanan Kesehatan Peduli Remaja (PKPR) di Puskesmas, Jakarta tahun 2005

Depkes RI, Pedoman perencanaan program kesehatan remaja bagi Tim Kabupaten Kota , Jakarta tahun 2005

Depkes RI, UNPFA, Deklarasi dan kerangka aksi Beijing bidang kritis" Perempuan dan Kesehatan serta program tindaklanjutnya, Jakarta 2005

Depkes RI, UNPFA, Keluarga Berencana, Kesehatan reproduksi, gender dan pembangunan kependudukan, Jakarta 2006

Kemenkes RI, Pedoman Standar Nasional Pelayanan Kesehatan Peduli Remaja (PKPR), Jakarta tahun 2014

Manuaba, Ida ayu chandra, Memahami Kesehatan Reproduksi wanita, cetakan 2, ECG Jakarta

Notoatmodjo Soekidjo, Metodelogi Penelitian kesehatan, Rineka Cipta Jakarta tahun 2010 